\title{
Chemical and thermal profile of Plectranthus amboinicus essential oil for its application as a bioherbicide
}

\author{
Perfil químico e térmico do óleo essencial de Plectranthus amboinicus visando sua aplicação
} como bioherbicida

\author{
J. Maldaner ${ }^{*}$; M. N. Oliveira ${ }^{2}$; D. A. Santos 2 ; P. T. Garcia ${ }^{2}$; S. Y. S. Silva ${ }^{2}$; S. C. \\ Silva $^{2}$; L. E. P. Lima ${ }^{2}$; F. S. Silva ${ }^{2}$ \\ ${ }^{I}$ Centro de Pesquisa em Florestas, Departamento de Diagnóstico e Pesquisa Agropecuária, Secretaria da \\ Agricultura, Pecuária e Desenvolvimento Rural do Rio Grande do Sul. 97001-970, Santa Maria-RS, Brasil \\ ${ }^{2}$ Faculdade de Química, Instituto de Ciencias Exatas, Universidade Federal do Sul e Sudeste do Pará - UNIFESSPA, \\ 68505-080, Marabá-PA, Brasil \\ *jomaldaner@gmail.com \\ (Recebido em 23 de março de 2021; aceito em 17 de novembro de 2021)
}

\begin{abstract}
The species Plectranthus amboinicus is an aromatic herb with great application in popular medicine due to the diversity of biological properties. Chemically, its essential oil (EO) is characterized by two chemotypes, thymol and carvacrol, which vary depending on factors such as seasonality. Despite being an extensively exploited species, studies of the bioherbicidal potential of this species are insufficient. In this context, the EO of $P$. amboinicus leaves, extracted in two different seasonal periods, were characterized regarding chemical profile (by gas chromatography mass spectrometry - GC-MS) and thermal profile (DTG) and was subjected to bioherbicide tests (germination test and seedling development) against Eragrostis plana, commonly known as capim annoni, an invader of pastures in the Pampas region. P. amboinicus EO was a potent inhibitor of $E$. plana germination, reducing accumulated germination by over $70 \%$ when exposed to $0.1 \% \mathrm{EO}$, and a complete inhibition of germination was observed when exposed to $0.5 \%$. Following the effects observed in germination, the initial growth of E. plana was significantly affected by concentrations above $0.05 \%$. The major constituent identified via GC-MS was carvacrol, representing $87.5 \%$ of the volatile composition of $P$. amboinicus leaves. In addition, P. amboinicus EO presented high thermal stability up to $100{ }^{\circ} \mathrm{C}$, which is an interesting result regarding its use as a bioproduct.
\end{abstract}

Keywords: essential oil, bioherbicide, derivative thermogravimetric.

Plectranthus amboinicus é uma espécie herbácea aromática com ampla aplicação na medicina popular devido a suas variadas propriedades biológicas. Quimicamente seu óleo essencial (OE) é caracterizado por dois quimiotipos, timol e carvacrol, que podem variar dependendo de diferentes fatores incluindo sazonalidade. Apesar de ser uma espécie amplamente explorada, os estudos do potencial bioherbicida desta espécie são insuficientes. Nesse contexto, OE das folhas de P. amboinicus, extraídos em dois períodos sazonais distintos, foram caracterizados quanto ao perfil químico (por cromatografia gasosa e espectrometria de massa - CG-EM), térmico (DTG) e submetido a testes bioherbicida (teste de germinação e desenvolvimento inicial de mudas) contra Eragrostis plana, vulgarmente conhecido como capim annoni, invasor de pastagens na região dos Pampas. O OE de P. amboinicus foi um potente inibidor da germinação de E. plana, reduzindo a germinação acumulada em mais de $70 \%$ quando exposto a $0,1 \%$ de OE, e uma inibição completa da germinação foi observada quando exposto a $0,5 \%$. Seguindo os efeitos observados na germinação, o crescimento inicial de E. plana foi significativamente afetado por concentrações acima de 0,05\%. O principal constituinte identificado por CG-EM foi o carvacrol, representando 87,5\% da composição volátil das folhas de $P$. amboinicus. Além disso, o $\mathrm{OE}$ de $P$. amboinicus apresentou alta estabilidade térmica até $100{ }^{\circ} \mathrm{C}$, o que é um resultado muito interessante quando se visa seu uso como bioproduto.

Palavras-chave: óleo essencial, bioherbicida, termogravimetria derivada.

\section{INTRODUCTION}

Plectranthus amboinicus, known as country borage, is a dicotyledonous plant belonging to the family Lamiaceae [1]. It is a large succulent aromatic perennial herb [2]. The species, known as "thick-mint", has been used for long as a medicinal plant for many diseases such as respiratory diseases, hepatopathy, renal and vesical calculi, to treat malarial fever, cough, chronic asthma, 
hiccough, bronchitis, helminthiasis, colic, convulsions, and epilepsy [3-5]. Some studies provide evidence for its folkloric medicinal uses, such as its analgesic and anti-inflammatory activities [6]. Patel et al. (2010) [7], found significant antioxidant activity. Moreover, antimicrobial [5, 8] and insecticidal potential [9] were investigated.

These properties are often attributed to the essential oils (EOs) of the species. Studies have revealed the presence of 76 volatile constituents in the $P$. amboinicus EO [10]. The prevalent presence of the phenolic compounds carvacrol and thymol has already been observed by several authors [9-11]. The quantitative participation of those chemotypes in the composition of the EO is variable and influenced by several factors.

Many external factors can influence the EOs biosynthesis, such as environmental and agronomic conditions [12-14], stress factors [15, 16], time of harvest and phenology [17-19], different parts of the plants used for the extraction [20,21] and even epigenetic changes resulting from concrete growing conditions [22, 23]. All those possible variations interfere with the action potential of EOs. Thus, this work aims to compare the chemical profile of the EO of P. amboinicus in two well-defined seasons, Amazonian winter/rainy season and Amazonian summer/dry season.

Although $P$. amboinicus EO is well studied, its bioherbicide potential was investigated for the first time in this study, where we tested its effect on germination and initial growth of Eragrostis plana Nees (Poaceae), the most abundant invasive plant in the pastures of southern Brazil. Rapid dispersion, facilitated by abundant seed production and allelopathic effects on other plants, made the species a difficult pest to control [24]. The impacts caused by this invasive species mainly refer to the replacement of native vegetation in many regions, which significantly impairs the feeding quality of the herd, causing considerable damage to livestock production [25].

With the intention of proposing a bioproduct for the control of E. plana, the P. amboinicus EO was also subjected to thermogravimetric analysis to evaluate the thermal behavior of the bioproduct, as well as its stability.

\section{MATERIAL AND METHODS}

\subsection{Plant material}

Plectranthus amboinicus leaves were harvested at a private vegetable garden in the city of

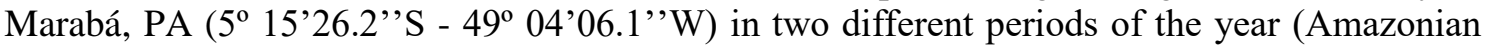
winter and summer). The botanical material was properly identified by Dr. Bernardo Tomchinsky from Universidade Federal do Sul e Sudeste do Pará (Unifesspa), with exsiccate in the herbarium of Casa da Cultura de Marabá, under registration number 6417.

Eragrostis plana seeds, originating from a batch of seeds collected in different cities in areas of the Pampa biome, central-southern region of Rio Grande do Sul (Hulha Negra, Dom Pedrito, São Gabriel and Santa Maria), were used in this study. Prior to the experiments, the seeds were stored in a refrigerator $\left( \pm 4^{\circ} \mathrm{C}\right)$.

\subsection{Essential oil extraction}

Plectranthus amboinicus air-dried leaves were ground through a Wiley mill equipped with either a l-mm or a 2-mm screen. The following process, hydrodistillation, was performed using Clevenger-type apparatus for three hours to obtain the EO. The oils obtained were dried over anhydrous sodium sulfate and total oil yields were calculated as the rate of the mass of the base vegetable and the oil mass obtained and expressed in percentage. Prior to chemical characterization and bioassays, the oil samples were stored in Eppendorf-type microtubes at $-4{ }^{\circ} \mathrm{C}$. 


\subsection{Chromatographic analysis}

The EO composition was analyzed in triplicate by gas chromatography coupled to the mass spectrometer using the Shimadzu GCMS-QP2010 Plus (Shimadzu Corporation, Kyoto, Japan) device equipped with autosampler (AOC - 5000 Plus from Shimadzu). A fused silica capillary column, Rtx - 5MS (30 m x $0.25 \mathrm{~mm} \times 0.25 \mu \mathrm{m})$ was used with helium as carrier gas at a constant flow of $1.23 \mathrm{~mL} / \mathrm{min}$. The injector and detector temperatures were adjusted to $250{ }^{\circ} \mathrm{C}$ and 280 ${ }^{\circ} \mathrm{C}$, respectively, and the injection volume was $1 \mu \mathrm{L}$ in split ratio $1: 10$. The oven temperature started at $40{ }^{\circ} \mathrm{C}$ and was kept for $3 \mathrm{~min}$, then increased to $240{ }^{\circ} \mathrm{C}$ at $4{ }^{\circ} \mathrm{C} / \mathrm{min}$ and kept for $5 \mathrm{~min}$, presenting a final time of 58.00 minutes of analysis. The mass spectrum was acquired in the range of $40 \mathrm{~m} / \mathrm{z}$ to $500 \mathrm{~m} / \mathrm{z}$. $70 \mathrm{eV}$ electron impact ionization energy was used.

In order to identify the individual components of the $\mathrm{EO}$, a mixture of hydrocarbons $\left(\mathrm{C}_{10} \mathrm{H}_{22}-\right.$ $\mathrm{C}_{40} \mathrm{H}_{82}$ ) was injected under the same conditions and identification of constituents was then performed by comparing the spectra obtained with those of the database and, considering the relative retention index (RRI), calculated for each constituent as previously described [26].

The quantitative analysis was performed with a gas chromatograph (Shimadzu GC 2010) equipped with a DB-5 column $(30 \mathrm{~m} \times 0.25 \mathrm{~mm} \times 0.25 \mu \mathrm{m}$, J \&W Scientific), an autosampler (AOC 20i) and a flame ionization detector (FID). The method conditions were the following: the initial temperature of the column oven was $40{ }^{\circ} \mathrm{C}$ and was kept for $3 \mathrm{~min}$, then increased to $240{ }^{\circ} \mathrm{C}$ at $4{ }^{\circ} \mathrm{C} / \mathrm{min}$ and kept for $5 \mathrm{~min}$. The carrier gas was hydrogen at $1.23 \mathrm{~mL} / \mathrm{min}$, and the injector and detector temperatures were 250 and $280^{\circ} \mathrm{C}$, respectively. The total time of analysis was 58.00 minutes and the injection volume was $1 \mu \mathrm{L}$ with split ratio 1:10.

\subsection{Thermogravimetric analysis}

Plectranthus amboinicus EO sample (19.037 $\mathrm{mg}$ ) was subjected to thermogravimetric analysis (TGA) using a Shimadzu equipment (DTG-60H model). The heating rate was $10^{\circ} \mathrm{C} / \mathrm{min}$ from room temperature $\left(25^{\circ} \mathrm{C}\right)$ to $700^{\circ} \mathrm{C}$. Air was employed as carrier gas in a flow rate of $50 \mathrm{~mL} / \mathrm{min}$.

\subsection{Bioherbicidal assays}

The EO from the dry season was diluted in absolute ethyl alcohol $(1: 1-\mathrm{v} / \mathrm{v})$ prior to the treatment composition to allow homogenization in aqueous solution. The experiments consisted of nine treatments: control (distilled water); alcohol control; and $0.005 ; 0.01 ; 0.05 ; 0.1 ; 0.5 ; 1.0$ and $1.5 \%(\mathrm{v} / \mathrm{v})$ of the EO diluted in alcohol. The alcohol control was established with the highest concentration of ethyl alcohol used in the dilution to eliminate any effects of alcohol in the treatments.

After mild disinfestation with distilled water, hypochlorite (2.5\%), commercial detergent and $70 \%$ alcohol, the E. plana seeds were arranged on blotter-type germination paper in germination boxes (Gerbox, capacity $250 \mathrm{~mL}, 11 \times 11 \times 3.5 \mathrm{~cm}$ ). The germination paper was moistened with the respective solution of each treatment in a volume of $5 \mathrm{~mL}$ per replicate. Every 4 days, $2 \mathrm{~mL}$ of this solution were applied to avoid dehydration. Four replicates were used per treatment, each one consisting of a germination box with 20 E. plana seeds. The tests were performed in a climatecontrolled chamber at a temperature of $25 \pm 2{ }^{\circ} \mathrm{C}$ and a photoperiod of 12 hours. For standardization purposes, a germinated seed was considered a seed that emitted a radicle of at least $2 \mathrm{~mm}$ in length. The following variables were evaluated:

Accumulated Germination - total of germinated seeds at 10 days after incubation. The results were expressed as percentages of germination.

Dead - were considered dead all non-germinated seeds and those that did not evolve to seedling after root protrusion.

Daily count of germinated seeds up to 10 days after incubation yielded the following indexes:

Germination Speed Index (GSI) - calculated by the following formula:

$\mathrm{GSI}=\mathrm{G} 1 / \mathrm{N} 1+\mathrm{G} 2 / \mathrm{N} 2+\ldots+\mathrm{Gn} / \mathrm{Nn}$. 
Germination Speed Coefficient (GSC) - calculated by the following formula:

$\mathrm{GSC}=\mathrm{G} 1+\mathrm{G} 2+\mathrm{G} 3+\ldots+\mathrm{Gn} /(\mathrm{G} 1 . \mathrm{N} 1+\mathrm{G} 2 . \mathrm{N} 2+\mathrm{G} 3 . \mathrm{N} 3+\ldots+\mathrm{Gn} . \mathrm{Nn})$,

Average Germination Time (AGT) - calculated by the following formula:

$\mathrm{AGT}=(\mathrm{G} 1 . \mathrm{N} 1+\mathrm{G} 2 . \mathrm{N} 2+\mathrm{G} 2 . \mathrm{N} 3 \ldots+\mathrm{Gn} . \mathrm{Nn}) /(\mathrm{G} 1+\mathrm{G} 2+\mathrm{G} 3+\ldots+\mathrm{Gn})$,

where: $\mathrm{G} 1, \mathrm{G} 2, \ldots \mathrm{Gn}=$ number of normal seedlings computed in the first count, the second count and the last count; $\mathrm{N} 1, \mathrm{~N} 2, \ldots \mathrm{Nn}=$ number of days of sowing at the first, second and last count [27].

The initial growth of the E. plana was evaluated at 10 days after sowing, when the height of the seedlings was measured with a ruler. The number of tillers was counted, and damage was estimated by assigning a rating scale ( 0 to 3 where 0 stands for "without damage") and the seedlings were dried in a drying oven at $60{ }^{\circ} \mathrm{C}$ until reaching a constant mass. Then, the dry mass was measured with an analytical scale.

\subsection{Statistical analysis}

The bioherbicidal experiments were repeated three times with four replicates per treatment, each consisting of a germination box with 20 E. plana seeds. The percentage data were previously submitted to arc sine transformation to meet the assumptions of the mathematical model. Subsequently, all variables were submitted to analysis of variance, and the mean values were compared by the Tukey test $(\mathrm{P}<0.05)$ using the statistical software SISVAR 5.6 [28].

\section{RESULTS AND DISCUSSION}

\subsection{Chemical profile}

The comparison between the oil yields obtained in winter $(0.2582 \pm 0.0781)$ and summer $(0.2680 \pm 0.0126)$, as well as the chemical profile of the EO samples, showed that the environmental conditions in these two periods of the year did not significantly affect the metabolism of $P$. amboinicus. Yields between $0.12 \%$ [11] and $0.43 \%$ [29] of EO from leaves have been reported for this species. From the analysis of the chemical profile, the predominance of terpene class was observed with the majority production of carvacrol chemotype, representing an average of $87.5 \%$ of the volatile composition of $P$. amboinicus leaves (Table 1). These results were in accordance with [30].

Table 1. Chemical profile of essential oil of Plectranthus amboinicus leaves.

\begin{tabular}{ccccccc}
\hline Peaks & $\begin{array}{c}\mathbf{R T}^{\mathbf{a}} \\
(\mathbf{m i n})\end{array}$ & Compounds & $\mathbf{I R}^{\mathbf{b}}$ & $\mathbf{I R}^{\mathbf{c}}$ & ${\text { Summer } \pm \mathbf{S D}^{\mathbf{d}}}^{\text {Winter }_{\mathbf{S}} \mathbf{S D}^{\mathbf{d}}}$ \\
\hline 1 & 4.13 & $\beta$-pinene & 995 & 979 & $0.14 \pm 0.06$ & $0.19 \pm 0.09$ \\
2 & 4.62 & $\alpha$-terpinene & 1025 & 1017 & $0.01 \pm 0.01$ & $0.01 \pm 0.00$ \\
3 & 4.75 & $p$-cimene & 1032 & 1024 & $1.01 \pm 0.46$ & $1.41 \pm 0.70$ \\
4 & 5.26 & $\gamma$-terpinene & 1064 & 1059 & $0.40 \pm 0.17$ & $0.60 \pm 0.29$ \\
5 & 5.51 & cis-Sabinene hydrate & 1080 & 1070 & $0.07 \pm 0.04$ & $0.09 \pm 0.05$ \\
6 & 6.00 & Linalool & 1108 & 1096 & $0.02 \pm 0.01$ & $0.03 \pm 0.01$ \\
7 & 6.09 & trans-Sabinene hydrate & 1113 & 1098 & $0.22 \pm 0.10$ & $0.29 \pm 0.14$ \\
8 & 7.31 & NI & 1175 & NI & $1.45 \pm 0.81$ & $1.51 \pm 0.38$ \\
9 & 7.52 & Borneol & 1185 & 1169 & $0.95 \pm 0.67$ & $1.15 \pm 0.48$ \\
10 & 7.68 & Terpinen-4-ol & 1193 & 1177 & $0.59 \pm 0.4$ & $0.30 \pm 0.19$ \\
11 & 8.04 & NI & 1211 & NI & $0.25 \pm 0.11$ & $0.12 \pm 0.02$ \\
12 & 8.67 & NI & 1240 & NI & $0.48 \pm 0.28$ & $0.63 \pm 0.27$ \\
13 & 9.36 & NI & 1273 & NI & $0.08 \pm 0.02$ & $0.05 \pm 0.01$ \\
14 & 9.75 & NI & 1291 & NI & $0.09 \pm 0.01$ & $0.07 \pm 0.03$ \\
15 & 9.91 & Thymol & 1299 & 1290 & $0.28 \pm 0.01$ & $0.26 \pm 0.03$ \\
\hline
\end{tabular}




\begin{tabular}{|c|c|c|c|c|c|c|}
\hline 16 & 9.97 & NI & 1301 & NI & $0.13 \pm 0.03$ & $0.09 \pm 0.02$ \\
\hline 17 & 10.07 & Carvacrol & 1306 & 1299 & $87.93 \pm 1.55$ & $87.62 \pm 1.35$ \\
\hline 18 & 12.69 & $E$-caryophyllene & 1430 & 1419 & $1.12 \pm 0.36$ & $1.25 \pm 0.54$ \\
\hline 19 & 12.88 & $\alpha$-trans-bergamotene & 1439 & 1434 & $0.45 \pm 0.16$ & $0.52 \pm 0.2$ \\
\hline 20 & 13.45 & $\alpha$-humulene & 1466 & 1454 & $0.30 \pm 0.09$ & $0.36 \pm 0.15$ \\
\hline 21 & 13.98 & NI & 1492 & NI & $0.02 \pm 0.02$ & $0.04 \pm 0.01$ \\
\hline 22 & 14.29 & $\alpha$-muurolene & 1507 & 1500 & $0.01 \pm 0.01$ & $0.04 \pm 0.03$ \\
\hline 23 & 14.55 & $\beta$-bisabolene & 1520 & 1505 & $0.01 \pm 0.01$ & $0.02 \pm 0.01$ \\
\hline 24 & 14.57 & NI & 1521 & NI & $0.02 \pm 0.01$ & $0.02 \pm 0.01$ \\
\hline 25 & 14.85 & NI & 1535 & NI & $0.02 \pm 0.01$ & $0.03 \pm 0.03$ \\
\hline 26 & 15.22 & cis-Sesquisabinene hydrate & 1554 & 1544 & $0.02 \pm 0.01$ & $0.07 \pm 0.1$ \\
\hline 27 & 15.45 & NI & 1565 & NI & $0.02 \pm 0.01$ & $0.05 \pm 0.03$ \\
\hline 28 & 16.04 & Caryophyllene oxide & 1595 & 1583 & $2.59 \pm 0.47$ & $1.92 \pm 0.35$ \\
\hline 29 & 16.39 & NI & 1613 & NI & $0.03 \pm 0.01$ & $0.02 \pm 0.01$ \\
\hline 30 & 16.52 & NI & 1620 & NI & $0.03 \pm 0.03$ & $0.03 \pm 0.03$ \\
\hline 31 & 16.60 & Humulene epoxide II & 1624 & 1608 & $0.44 \pm 0.13$ & $0.35 \pm 0.05$ \\
\hline 32 & 17.04 & NI & 1647 & NI & $0.02 \pm 0.01$ & $0.03 \pm 0.01$ \\
\hline 33 & 17.18 & $\begin{array}{l}\text { Caryophylla-4(12),8(13)- } \\
\text { dien-5-ol }\end{array}$ & 1655 & 1640 & $0.04 \pm 0.02$ & $0.04 \pm 0.01$ \\
\hline 34 & 17.56 & NI & 1675 & NI & $0.01 \pm 0.01$ & $0.01 \pm 0.01$ \\
\hline 35 & 17.75 & $\begin{array}{l}\text { 14-hydroxy-(Z)- } \\
\text { Caryophyllene }\end{array}$ & 1685 & 1667 & $0.19 \pm 0.09$ & $0.29 \pm 0.07$ \\
\hline 36 & 17.86 & $\begin{array}{l}\text { 14-hydroxy-9-epi-(E)- } \\
\text { Caryophyllene }\end{array}$ & 1691 & 1669 & $0.14 \pm 0.06$ & $0.08 \pm 0.01$ \\
\hline 37 & 18.52 & NI & 1725 & NI & $0.03 \pm 0.02$ & $0.04 \pm 0.04$ \\
\hline 38 & 18.72 & 14-hydroxy- $\alpha$-Humulene & 1736 & 1714 & $0.02 \pm 0.02$ & $0.05 \pm 0.03$ \\
\hline 39 & 20.21 & NI & 1816 & NI & $0.02 \pm 0.02$ & $0.00 \pm 0.01$ \\
\hline 40 & 20.82 & NI & 1854 & NI & $0.03 \pm 0.03$ & $0.02 \pm 0.03$ \\
\hline 41 & 21.00 & NI & 1865 & NI & $0.02 \pm 0.01$ & $0.03 \pm 0.03$ \\
\hline 42 & 21.67 & NI & 1906 & NI & $0.02 \pm 0.02$ & $0.02 \pm 0.02$ \\
\hline 43 & 22.07 & NI & 1931 & NI & $0.02 \pm 0.02$ & $0.04 \pm 0.05$ \\
\hline 44 & 23.68 & NI & 2030 & NI & $0.03 \pm 0.02$ & $0.02 \pm 0.02$ \\
\hline 45 & 23.86 & NI & 2041 & NI & $0.02 \pm 0.01$ & $0.01 \pm 0.01$ \\
\hline 46 & 24.10 & NI & 2056 & NI & $0.04 \pm 0.03$ & - \\
\hline 47 & 24.19 & NI & 2062 & NI & $0.01 \pm 0.01$ & $0.01 \pm 0.01$ \\
\hline 48 & 24.28 & NI & 2068 & NI & $0.01 \pm 0.01$ & $0.02 \pm 0.03$ \\
\hline 49 & 24.64 & NI & 2091 & NI & $0.02 \pm 0.02$ & $0.01 \pm 0.01$ \\
\hline 50 & 25.10 & NI & 2121 & NI & $0.02 \pm 0.01$ & $0.01 \pm 0.01$ \\
\hline 51 & 25.23 & NI & 2129 & NI & $0.03 \pm 0.03$ & $0.03 \pm 0.02$ \\
\hline 52 & 25.42 & NI & 2142 & NI & $0.02 \pm 0.02$ & $0.03 \pm 0.01$ \\
\hline 53 & 25.67 & NI & 2159 & NI & $0.03 \pm 0.02$ & $0.04 \pm 0.03$ \\
\hline 54 & 26.29 & NI & 2200 & NI & $0.02 \pm 0.01$ & $0.01 \pm 0.01$ \\
\hline 55 & 31.58 & $\begin{array}{l}\text { NI } \\
\text { Total identified }\end{array}$ & 2588 & NI & $\begin{array}{l}0.02 \pm 0.01 \\
\mathbf{9 6 . 9 5}\end{array}$ & $\begin{array}{l}0.01 \pm 0.00 \\
\mathbf{9 6 , 9 6}\end{array}$ \\
\hline
\end{tabular}

${ }^{\mathrm{a}}$ Retention Time; ${ }^{\mathrm{b}}$ Experimental Retention Index; ${ }^{\mathrm{c}}$ Literature Retention Index; ${ }_{\mathrm{d}}^{\mathrm{d}}$ Standard Deviation ${ }^{\mathrm{e}}$ Not Identified.

\subsection{Thermal profile}

By using the TGA tests, it was possible to build graphs presenting the weight loss curve and the derivative thermogravimetric (DTG) curve, as can be seen in Figure 1. 


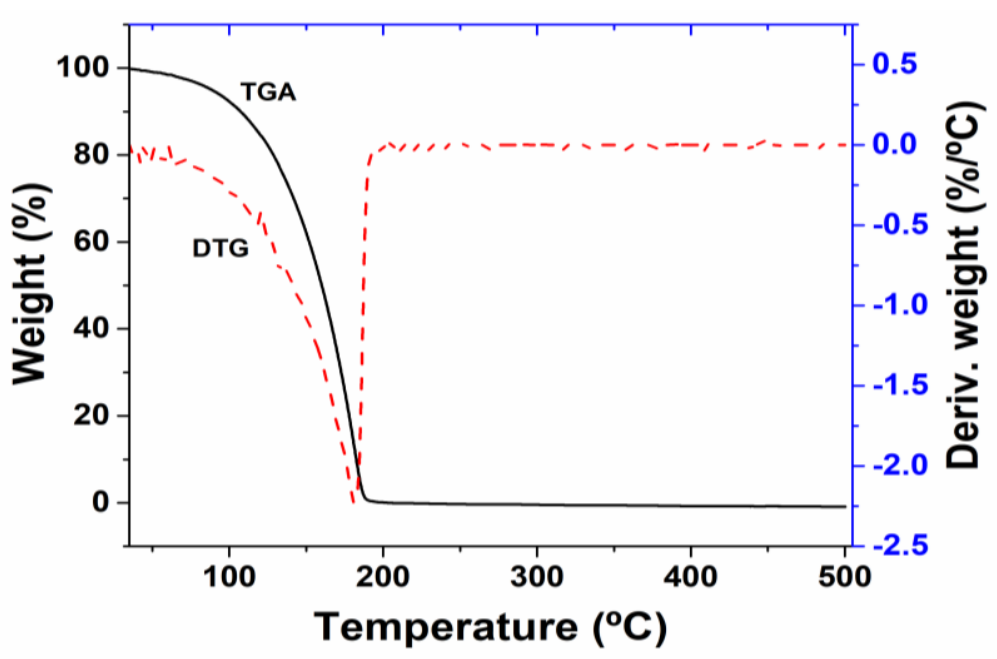

Figure 1. Representation of TGA (solid black line) and DTG (dashed red line) curves for Plectranthus amboinicus essential oil.

TGA graphic presented just a single decomposition step, representing a weight loss of $99.04 \%$ on the temperature range from $100{ }^{\circ} \mathrm{C}$ to $190{ }^{\circ} \mathrm{C}$, and this result agrees with what was previously reported in the literature [30] considering the related plant is of the carvacrol chemotype. The TGA analysis showed that the EO used in this study has a high thermal stability until $100{ }^{\circ} \mathrm{C}$, which is an important result taking into account the proposal to use the referred $\mathrm{EO}$ as bioherbicide against a species of E. plana, which is invasive of pasture, and thus encourages researchers in order to demonstrate the proof-of-concept of this present study.

\subsection{Bioherbicidal assays}

The bioherbicidal potential of the EO of $P$. amboinicus leaves did not statistically differ in the different collection seasons, Amazonian winter/rainy season and Amazonian summer/dry season (data not shown). Thus, the presented results refer to the oil from the dry season.

The P. amboinicus EO proved to be a potent inhibitor of E. plana germination. Accumulated germination was reduced by over $70 \%$ on exposure to $0.1 \%$ EO of $P$. amboinicus and a complete inhibition of germination was observed from $0.5 \%$. Consequently, mortality followed this response, reaching $100 \%$ from $0.5 \%$ EO. Regarding germination speed data (GSI, GSC and AGT), it was possible to observe a delay in germination from the concentration of $0.05 \%$ EO (Table 2). Although in this study an evident reduction in the germination rate was soon perceived, in some cases the allelopathic effect in plants is most often expressed not by the amount of germinated seeds, but rather by the retardation of their germination [31]. The retardation can give the necessary time to harvest the crop without loss in its production.

Table 2. Plectranthus amboinicus essential oil on Eragrostis plana germination.

\begin{tabular}{cccccc}
\hline Treatments & $\begin{array}{c}\text { Accumulated } \\
\text { germination (\%) }\end{array}$ & Dead (\%) & GSI & GSC & AGT \\
\hline Control & $81.67 \mathrm{a}^{*}$ & $18.33 \mathrm{~d}$ & $5.47 \mathrm{a}$ & $0.27 \mathrm{a}$ & $3.82 \mathrm{c}$ \\
Alcohol Control & $75.00 \mathrm{a}$ & $25.00 \mathrm{~d}$ & $4.78 \mathrm{a}$ & $0.24 \mathrm{a}$ & $4.13 \mathrm{c}$ \\
$\mathbf{0 . 0 0 5} \%$ & $21.67 \mathrm{bc}$ & $78.33 \mathrm{bc}$ & $2.04 \mathrm{bc}$ & $0.20 \mathrm{abc}$ & $4.94 \mathrm{bc}$ \\
$\mathbf{0 . 0 1} \%$ & $31.67 \mathrm{~b}$ & $68.33 \mathrm{c}$ & $2.54 \mathrm{~b}$ & $0.23 \mathrm{ab}$ & $4.44 \mathrm{c}$ \\
$\mathbf{0 . 0 5} \%$ & $15.00 \mathrm{~cd}$ & $85.00 \mathrm{ab}$ & $0.69 \mathrm{~cd}$ & $0.15 \mathrm{bc}$ & $6.64 \mathrm{ab}$ \\
$\mathbf{0 . 1} \%$ & $8.33 \mathrm{~cd}$ & $91.67 \mathrm{ab}$ & $0.28 \mathrm{~cd}$ & $0.14 \mathrm{c}$ & $6.83 \mathrm{a}$ \\
$\mathbf{0 . 5} \%$ & $0 \mathrm{~d}$ & $100 \mathrm{a}$ & ng** & ng & ng \\
\hline
\end{tabular}

* Means followed by the same letter in the column do not differ by Tukey test at 5\% probability. GSI: germination speed index; GSC: germination speed coefficient; AGT: average germination time; CV: Coefficient of Variation. ** ng: non-germinated. 
Following the effects observed in germination, the initial growth of $E$. plana was significantly affected by concentrations above $0.05 \%$ of the P. amboinicus EO (Figure 2 ).
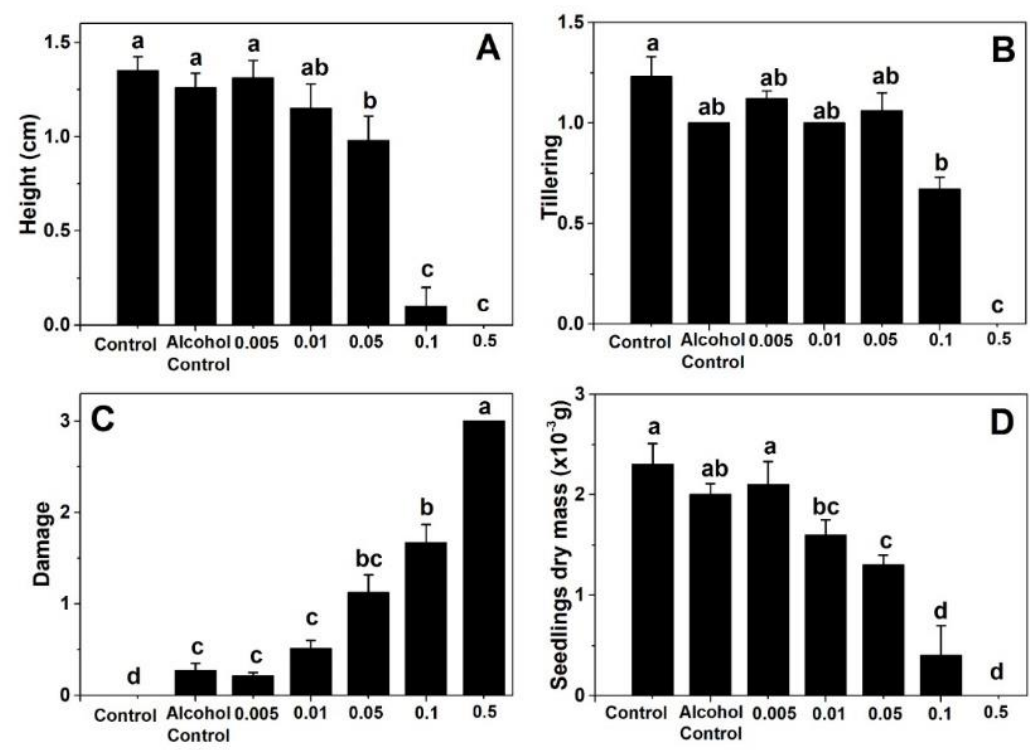

Essential oil concentration (\%)

Figure 2. Concentrations of Plectranthus amboinicus essential oil in the initial growth of Eragrostis plana. A: Seedlings height (cm); B: Tillering; C: Damage; D: Seedlings dry mass ( $\mathrm{g}$ ).

Allelopathic effects of this species had already been shown by El-Rokiek et al. (2018) [32], who showed that aqueous extracts from $P$. amboinicus leaves were a potent inhibitor of the growth of weeds (Phalaris minor and Anagalis arvensis) present in the cultivation of peas (Pisum sativum). Furthermore, the authors demonstrated a higher productivity in the cultivation of $P$. sativum using $25 \%$ P. amboinicus leaf extract.

Several biological activities have previously been attributed to the isomeric chemotypes thymol and carvacrol, such as antifungal activity [33-36], insecticide, phytotoxic among others $[33,37]$.

Pinheiro et al. (2015) [11] reported that the EO of P. amboinicus and its chemotypes, carvacrol and thymol, inhibited the germination and decreased root and aerial growth of Lactuca sativa and Sorghum bicolor. Lima et al. (2019) [38] tested thymol in seed treatment; they noted that thymol did not impair the germination and the GSI of soybean seeds. Instead, the use of high concentrations affected the seedling phenotype; doses up to $1 \mathrm{mg} / \mathrm{L}$ of thymol showed deleterious effects on roots and seedlings. Moreover, Assis Alves et al. (2018) [35] verified that inhibition of germination brought by thymol in weed species was as intensive as the germination suppression promoted by the synthetic herbicide dichlorophenoxyacetic acid (2,4-D).

Motivated by the research carried out by Bendre et al. (2018) [39], who compiled studies highlighting the extensive effects of carvacrol on various agricultural pests, it is suggested that the allelopathic effects of $P$. amboinicus, found in this study, can be attributed to this main constituent of its EO, the carvacrol.

Previous studies demonstrate the mechanism of action of carvacrol which may also be occurring for the inhibition of germination and initial growth verified in the present study. For example, Gill and Holley (2006) [40] observed that carvacrol at the concentration of 5.0 or 10 $\mathrm{mmol} / \mathrm{L}$ caused inhibition of the activity of enzyme adenosine triphosphatase (ATPase), which is responsible for catalyzing the process of breaking adenosine triphosphate (ATP) into adenosine diphosphate (ADP) plus inorganic phosphate. The impairment of this metabolic pathway impacts several physiological processes for plant growth and development, both pre and post germination [41]. 
A more recent study verified the potential of carvacrol, as well as other compounds, in controlling weeds Amaranthus retroflexus, Avena fatua, Eleocharis bonariensis, and Portulaca oleracea and could be a good candidate for bioherbicide formulations. This study also confirmed that the exposure time and the applied concentration influenced the degree of toxicity [42].

Thus, the present study corroborates the previously registered research and presents the EOs of $P$. amboinicus leaves as a potential matrix for the development of a bioproduct to be explored as a bioherbicide in the control of E. plana, due to the high efficiency in the control of germination and initial growth of this invader $(0.1 \%)$. In addition, both the plant and its constituents of EO are considered safe for the environment and human health since they are used in flavorings and food infusions in traditional medicine.

\section{CONCLUSION}

In the perspective of the application of natural products as bioherbicides, in this work the $P$. amboinicus essential oils were analyzed for their chemical and thermal profile and subjected to tests aimed at inhibiting germination and development of E. plana. The high efficiency in E. plana control presented by essential oils $(0.1 \%)$, as well as thermal stability up to $100{ }^{\circ} \mathrm{C}$ encourages the development of complementary studies necessary for the formulation of a bioproduct with bioherbicidal properties to combat this weed.

This is the first study that searched the bioherbicide potential of $P$. amboinicus essential oil against E. plana, an invasive species that is difficult to control.

\section{ACKNOWLEDGEMENTS}

The authors thank the Brazilian Funding Agencies (CNPq process numbers 406759/2018-9; FAPESPA process number 2010/110805) for the financial support. The authors would also like to express their gratitude to the institutions Casa da Cultura de Marabá and Instituto de Química de São Carlos da Universidade de São Paulo for granting part of the necessary infrastructure to execute the present work. They also thank Prof. Bernardo Tomchinsky for the botanical identification of $P$. amboinicus and Danillo Almeida for the English language review of this paper.

\section{REFERENCES}

1. Warrier PS. Indian Medicinal Plants: a compendium of 500 species. Arya vaidya sala, Kott akkal. Hyderabad (IN): Orient Longmann Limited; 1994. 315 p.

2. Kaliappan ND, Viswanathan PK. Pharmacognostical studies on the leaves of Plectranthus amboinicus (Lour) Spreng. Int J Green Pharm. 2008:182-4. doi: 10.4103/0973-8258.42740

3. Chopra RN, Nayar SL, Chopra IC. The glossary of Indian medicinal plants. New Delhi (IN): CSIR; 1956.

4. Nadkarni AK. Indian materia medica. 2nd ed. Mumbai (IN): Popular Prakashan; 1996. 371 p.

5. Santos FAV, Serra CG, Bezerra RJAC, Figueiredo FG, Matias EFF, Menezes IRA, et al. Antibacterial activity of Plectranthus amboinicus Lour (Lamiaceae) essential oil against Streptococcus mutans. Eur J Int Med. 2016;8(3):293-7. doi: 10.1016/j.eujim.2015.11.021

6. Chiu Y-J, Huang T-H, Chiu C-S, Lu T-S, Chen Y-W, Peng W-H, et al. Analgesic and antiinflammatory activities of the aqueous extract from Plectranthus amboinicus (Lour.) Spreng. Both In Vitro and In Vivo. Evid Based Complement Altern Med. 2012;2012:508137. doi: 10.1155/2012/508137

7. Patel RD, Mahobia NK, Singh MP, Singh A, Sheikh NW, Alam G, et al. Antioxidant potential of leaves of Plectranthus amboinicus (Lour) Spreng. Schol. Res Lib Der Pharm. Lett. 2010;2(4):240-5.

8. Bhatt P, Negi PS. Antioxidant and antibacterial activities in the leaf extracts of indian borage (Plectranthus amboinicus). Food Nutr Sci. 2012;3:146-52. doi: 10.4236/fns.2012.32022

9. Senthilkumar A, Venkatesalu V. Chemical composition and larvicidal activity of the essential oil of Plectranthus amboinicus (Lour.) Spreng against Anopheles stephensi: a malarial vector mosquito. Parasitol Res. 2010;107:1275-8. doi: 10.1007/s00436-010-1996-6 
10. Arumugam G, Swamy MK, Sinniah UR. Plectranthus amboinicus (Lour.) Spreng: Botanical, Phytochemical, Pharmacological and Nutritional Significance. Molecules. 2016;21(4):369. doi: 10.3390 /molecules21040369

11. Pinheiro PF, Costa AV, Alves TA, Galter IN, Pinheiro CA, Pereira AF, Oliveira CMR, Fontes MMP. Phytotoxicity and cytotoxicity of essential oil from leaves of Plectranthus amboinicus, carvacrol, and thymol in plant bioassays. J Agric Food Chem. 2015;63(41):8981-90. doi: 10.1021/acs.jafc.5b03049

12. Ormeño E, Olivier R, Jean-Philippe M, Baldy V, Fernandez C. Compost may affect volatile and semivolatile plant emissions through nitrogen supply and chlorophyll fluorescenceri. Chemosphere. 2009;77:94-104. doi: 10.1016/ j.chemosphere.2009.05.014

13. Tibaldi G, Fontana E, Nicola S. Growing conditions and postharvest management can affect the essential oil of Origanum vulgare L. ssp. Hirtum (Link) Ietswaart. Ind Crops Prod. 2011;34(3):151622. doi: 10.1016/j.indcrop.2011.05.008

14. Yosr Z, Hnia C, Rim T, Mohamed B. Changes in essential oil composition and phenolic fraction in Rosmarinus officinalis L. var. typicus Batt. organs during growth and incidence on the antioxidant activity. Ind. Crops and Prod. 2013; 43:412-9. doi: 10.1016/j.indcrop.2012.07.044

15. Bettaieb I, Nakhama N, Aidi Wannes W, Kchouk ME, Marzouk BR. Water deficit affects on Salvia officinalis fatty acids and essential oils composition. Sci Hortic. 2009;210:271-5. doi: 10.1016/ j.scienta.2008. 10.016

16. Selmar D, Mark K. Influencing the product quality by deliberately applying drought stress during the cultivation of medicinal plants. Ind Crops Prod. 2013;42:558-66. doi: 10.1016/ j.indcrop.2012.06.020

17. Jordán MJ, Martínez RM, Goodner KL, Baldwin EA, Sotomayor JA. Seasonal variation of Thymus hyemalis Lange and Spanish Thymus vulgaris essential oils composition. Ind Crops Prod. 2006;24:25363. doi: $10.1016 /$ j.indcrop. 2006.06.011

18. Moghaddam M, Pirbalaouti AG, Mehdizadeh L, Pirmoradi MR. Changes in composition and essential oil yield of Ocimum ciliatum at different phenological stages. Eur Food Res Technol. 2015; 40:99-204. doi: 0.1007/ s00217-014-2320-y

19. Smitha GR, Virendra RS. Variations in essential oil yield, geraniol and geranyl aceate contents in palmarosa (Cymbopogon martini, Roxb. Wats. Var. motia) influenced by inflorescence development. Ind Crops Prod. 2015;6:150-60. doi: 10.1016/ j.indcrop. 2014. 12.062

20. Bettaieb I, Bourgou S, Wannes WA, Hamrouni I, Limam F, Marzouk B. Essential oils, phenolics and antioxidant activities of different parts of cumin (Cominum cymimum L.). J Agric Food Chem. 2010;58(19):10410-8. doi: 10.1021/jf102248j

21. Ben Marzoug HN, Romdhane M, Lebrihi A, Mathieu F, Couderc F, Abderraba M, et al. Eucalyptus oleosa essential oils: chemical composition and antimicrobial and antioxidant activities of the oils from different plant parts (stems, leaves, flowers and fruits). Molecules. 2011;16:1695-709. doi: 10.3390/molecules 16021695

22. Lavania UC, Srivastava S, Lavania S, Basu S, Misra NK, Mukai Y. Autopolyploidy differentially influences body size in plants, but facilitates enhanced accumulation of secondary metabolites, causing increased cytosine methylation. Plant J. 2012;71:539-49. doi: 10.1111/j.1365- 313X.2012.05006.x

23. Ohlsson AB, Segerfeldt P, Lindströn A, Borg-Karlson A-K, Berglund T. UV-B exposure of indoorgrown Picea abies seedlings causes an epigenetic effect and selective emission of terpenes. Zeitschrift für Naturforschung C. 2013;68:139-47. doi: 10.5560/ZNC.2013.68c0139

24. Scheffer-Basso SM, Cecchin K, Favaretto A. Dynamic of dominance, growth and bromatology of Eragrostis plana Nees in secondary vegetation area. Rev Ciênci Agron. 2016;47(3):582-8. doi: 10.5935/1806-6690.20160070

25. Barbosa FG, Pillar VD, Palmer AR, Melo AS. Predicting the current distribution and potential spread of the exotic grass Eragrostis plana Nees in South America and identifying a bioclimatic niche shift during invasion. Aust Ecol. 2013;38:260-7. doi: 10.1111/j.1442-9993.2012.02399.x

26. Adams RP. Identification of essential oil components by gas chromatography/mass spectroscopy. 4. ed. Illinois (US): Allured Publishing Corporation; 2007. 804 p.

27. Maguire JD. Speed of germination-aid in selection and evaluation for seedling emergence and vigor. Crop Sci. 1962;2(1):176-7.

28. Ferreira DF. Sisvar: a computer statistical analysis system. Ciênc Agrotec. 2011;35(6):1039-42. doi: 10.1590/S1413-70542011000600001

29. Bandeira JM, Barbosa FF, Barbosa LMP, Rodrigues ICS, Bacarin MA, Peters JÁ, et al. Composição do óleo essencial de quatro espécies do gênero Plectranthus. Rev Bras Pl Med. 2011;13(2):157-64. doi: 10.1590/S1516-05722011000200006

30. Lopes PQ, Carneiro FB, Souza ABL, Santos SG, Oliveira EE, Soares LAL. Technological evaluation of emulsions containing the volatile oil from leaves of Plectranthus Amboinicus Lour. Pharmacogn Mag. 2017;13(49):159-67. doi: 10.4103/0973-1296.197646 
31. Ignanci JRV, Heiden VLB, Stein GVC, Rocha BHG. Efeito do extrato aquoso de diferentes espécies de boldo sobre a germinação e índice mitótico de Allium cepa L. Arq Inst Biol. 2006;73(1):79-82.

32. El- Rokiek KG, El-Din SAS, El- Wakeel MA, Dawood MG, El- Awadi ME. Allelopathic effect of the two medicinal plants Plectranthus amboinicus (Lour.) and Ocimum basilicum L. on the growth of Pisum sativum L. and associated weeds. Middle East J Agric Res. 2018;7(3):1146-53.

33. Kordali S, Cakir A, Ozer H, Cakmakci R, Kesdek M, Mete E. Antifungal, phytotoxic and insecticidal properties of essential oil isolated from Turkish Origanum acutidens and its three components, carvacrol, thymol and p-cymene. Bioresour Technol. 2008;99(18):8788-95. doi: 10.1016/j.biortech.2008.04.048

34. Miñambres L, Sanchez MN, Castano F, Basterretxea FJ. Hygroscopic properties of 10 internally mixed particles of ammonium sulfate and succinic acid studied by infrared spectroscopy. J Phys Chem A. 2010;114:6124-30. doi: 10.1021/jp101149k

35. Alves TA, Pinheiro PF, Praça-Fontes M, Andrade-Vieira LF, Corrêa KB, Alves TA, et al. Toxicity of thymol, carvacrol and their respective phenoxyacetic acids in Lactuca sativa and Sorghum bicolor. Ind Crops Prod. 2018;114:59-67. doi: 10.1016/j.indcrop.2018.01.071

36. Zhang J, Ma S, Du S, Chen S, Sun H. Antifungal activity of thymol and carvacrol against postharvest pathogens Botrytis cinerea. J Food Sci Tech MYS. 2019; 56(5):2611-20. doi: 10.1007/s13197-019$03747-0$

37. Campos EVR, Proença PLF, Oliveira JL, Pereira AES, Ribeiro LNM, Fernandes FO, et al. Carvacrol and linalool co-loaded in $\beta$-cyclodextrin-grafted chitosan nanoparticles as sustainable biopesticide aiming pest control. Sci Rep 2018; 8(1):1-14. doi: 10.1038/s41598-018-26043-x

38. Lima ELF, Macedo WR, Silva GH. Effect of Thymol on Soybean Seeds Germination: Physiological and Biochemical Analysis. Braz Arch Biol Technol. 2019;62:e19180251. doi: 10.1590/1678-43242019180251

39. Bendre R, Bagul S, Rajput J. Carvacrol: an excellent natural pest control agent. Nat Prod Chem Res. 2018;6(6):1-3. doi: 10.4172/2329-6836.1000349

40. Gill AO, Holley RA. Inhibition of membrane bound ATPases of Escherichia coli and Listeria monocytogenes by plant oil aromatics. Int J Food Microbiol. 2006;111(2):170-4. doi: 10.1016/j.ijfoodmicro.2006.04.046

41. Calinskan M, Bashiardes S, Cuming AC. A plasma membrane H+ATPase gene is germinationinduced in wheat embryos. Afr J Biotechnol. 2010;9(3):268-72.

42. Muñoz M, Torres-Pagán N, Peiró R, Guijarro R, Sánchez-Moreiras AM, Verdeguer M. Phytotoxic effects of three natural compounds: pelargonic acid, carvacrol, and cinnamic aldehyde, against problematic weeds in mediterranean crops. Agron. 2020;10(791):1-20. doi: 10.3390/agronomy 10060791 